\title{
Amino acid absorption and production of pancreatic hormones in non-anaesthetized pigs after duodenal infusions of a milk enzymic hydrolysate or of free amino acids
}

\author{
BY A. RÉRAT AND C. SIMOES NUNES \\ Laboratoire de Physiologie de la Nutrition, INRA, Centre de Recherches de \\ Jouy-en-Josas, 78350 Jouy-en-Josas, France \\ AND F. MENDY AND L. ROGER \\ Laboratoire Sopharga, 5 Rue Bellini, 92806 Puteaux, France
}

(Received 6 July 1987 - Accepted 16 February 1988)

\begin{abstract}
1. Six non-anaesthetized pigs (mean body-weight $57.0 \mathrm{~kg}$ ) were used to study the intestinal absorption of amino acids (AA) from either an enzymic hydrolysate of milk (PEP) containing a large percentage of small peptides (about $50 \%$ with less than five AA residues) and very few free AA ( $8 \%$ ), or from a mixture of free AA with an identical pattern (AAL) infused intraduodenally in one of two amounts (55 or $110 \mathrm{~g}$ ). Concomitant insulin and glucagon production rates were estimated.

2. Each pig was previously fitted, under anaesthesia, with an electromagnetic flow probe around the portal vein, with permanent catheters in the portal vein, the carotid artery and the duodenum. Each infusion was performed after an $18 \mathrm{~h}$ fasting period and each pig received each infusion. The observation period lasted for $5 \mathrm{~h}$.

3. The absorption of AA was greater, more rapid and more homogeneous after PEP infusion than after AAL infusion, independent of the amount infused.

4. For the majority of AA considered individually, the absorption coefficient was higher after infusion of PEP than after that of AAL. The exceptions were methionine with a higher absorption coefficient after AAL infusion, and isoleucine, aspartic acid + asparagine and glutamic acid + glutamine with identical coefficients for both infusions.

5. Some AA, such as asparagine, ornithine, citrulline and taurine, while absent in the infusates, appeared in the portal vein in appreciable amounts after the infusion of both solutions. While a small proportion of taurine may arise from recycling of taurine-containing bile salts, it seems that the gut wall is able to synthesize all four AA.

6. Insulin production did not differ according to the nature or amount of solutions infused. Glucagon production was greater after PEP infusion.
\end{abstract}

Like free amino acids (AA), small peptides may be transported by the enterocyte (Matthews \& Adibi, 1976). Their transport is associated with membrane or cytosol hydrolysis (Kim et al. 1974) and their AA are taken up by portal blood. There is evidence that the intestinal transport systems for small peptides are different from those for free AA (Sleisenger et al. 1976) and this might minimize the competition for transport sites and increase the efficiency of absorption.

In most of the in vivo experiments on this topic, the estimation criteria were either the rate of disappearance of nitrogenous matter from infused intestinal loops (Silk et al. 1982) or the rate of appearance of $\alpha$-amino-nitrogen in the peripheral blood (Chung et al. 1979). However, under these conditions the spatio-temporal capacities of the gut for digestive compensation could not function; in addition, the absorptive potential was not accurately estimated because variations in systemic blood were moderated by the hepatic uptake of AA. For these reasons the present study was carried out in non-anaesthetized pigs in order to quantify the appearance of AA in portal blood and the concomitant production of insulin and glucagon after duodenal infusion of a mixture containing mainly small peptides or a solution of AA of the same composition. Preliminary and partial results of the present experiment have been briefly reported elsewhere (Rérat et al. 1984, 1985b). 
Table 1. Amino acid $(A A)$ composition and peptide molecular weight $(M W)$ distribution of the milk-protein hydrolysate*

\begin{tabular}{|c|c|c|c|}
\hline \multirow{2}{*}{$\begin{array}{l}\text { AA composition }(\mathrm{g} / \mathrm{kg}) \\
\begin{array}{l}\text { MW distribution } \\
(\%)\end{array}\end{array}$} & \multicolumn{3}{|c|}{$\begin{array}{l}\text { Isoleucine } 51 \text {, leucine } 101 \text {, lysine } 85 \text {, methionine } 23 \text {, cystine } 16 \text {, phenyl- } \\
\text { alanine } 46 \text {, tyrosine } 49 \text {, threonine } 44 \text {, tryptophan } 18 \text {, valine } 59 \text {, arginine } \\
33 \text {, histidine } 25 \text {, alanine } 36 \text {, aspartic acid } 84 \text {, glutamic acid } 159 \text {, glycine } \\
18 \text {, proline } 84 \text {, serine } 47\end{array}$} \\
\hline & $\begin{array}{c}<1500 \dagger \\
80\end{array}$ & $\begin{array}{c}1500>\mathrm{MW}<5000 \\
17\end{array}$ & $\begin{array}{c}5000>\mathrm{MW}<6000 \\
3\end{array}$ \\
\hline $\begin{array}{l}\text { Free AA (mol \% of } \\
\text { mixture) }\end{array}$ & \multicolumn{3}{|c|}{8} \\
\hline
\end{tabular}

* Nitrogen content $126.78 \mathrm{~g} / \mathrm{kg}$.

+ More than $60 \%$ with less than five AA residues.

\section{MATERIALS AND METHODS}

\section{Animals}

Six castrated male Large White pigs (initial body-weight 57 (SEM 0.99) $\mathrm{kg}$ ) were used and experiments were conducted according to the guiding principles for care and use of laboratory animals (Biological Council, 1984). For 1 month before the experiment, they were fed on a well-balanced diet $(800-1000 \mathrm{~g} /$ meal), twice daily at 09.00 and 17.00 hours. The mean growth of the animals before the trial was $600 \mathrm{~g} / \mathrm{d}$. Each animal was fitted with an electromagnetic flow probe for measurement of the blood flow-rate in the portal vein, and with two catheters, one placed in the portal vein, the other in the left brachiocephalic arterial trunk through the carotid route (Rérat et al. 1980). During the surgical intervention, a sterile sylastic catheter $(1.98 \mathrm{~mm}$ internal diameter) was fastened in the duodenum through a hole in the centre of a purse-string ligature (silk no. 3) prepared previously, approximately $100 \mathrm{~mm}$ distal to the pylorus. The catheter extended $30-40 \mathrm{~mm}$ into the duodenum in a distal direction. The purse-string was tightened around the catheter which was fastened to duodenal muscular layers in front of its entrance site using a self-tightening loop so as to be located parallel to the duodenum. An outer abdominal opening approximately $20 \mathrm{~mm}$ long was made for the catheter and the tips of the ligature were used to fasten the duodenum to the abdomen at the entrance site of the catheter. The rest of the surgical procedure has been reported elsewhere (Rérat et al. 1980).

\section{Experimental infusions}

Before surgery and until the end of the experiment, the animals were placed in cages with easy access to catheters. Experiments began between 6 and $8 \mathrm{~d}$ after the surgery and when the animals had recovered a normal appetite and growth rate.

Each animal was subjected to four trials at 3-4 d intervals. Each started at 09.00 hours after a fasting period of $18 \mathrm{~h}$ and lasted $5 \mathrm{~h}$. In each trial, two different products, milkprotein hydrolysate (PEP) or a free AA solution (AAL) of the same composition (Table 1), were infused in one of two amounts $(55 \mathrm{~g}$ in $500 \mathrm{ml}$ water or $110 \mathrm{~g}$ in $1000 \mathrm{ml}$ water). Twothirds of the PEP were composed of the products of mild hydrolysis of milk (Rérat et al. $1985 \mathrm{~b}$ ) obtained at $38^{\circ}$ in an enzymic membrane reactor by the action of chymotrypsin on whey proteins (one-third) and casein (one-third), and the remaining third was composed of a mixture of non-phosphorylated peptides extracted from the enzymic casein hydrolysate. The vitamins and trace element contents of the PEP and AAL solutions were the same and that of minerals was adjusted so as to obtain equal osmotic pressures in the two 
experimental solutions. Infusion of the two preparations lasted $30 \mathrm{~min}$. The infusion sequence was a double Latin square design to control the influence of the sequence of experimental treatments.

\section{Measurements}

On the day of each perfusion, portal blood flow-rate was recorded continuously and $4 \mathrm{ml}$ samples of blood were taken simultaneously from the portal vein and carotid artery from the start until $5 \mathrm{~h}$ after the beginning of infusion, every $15 \mathrm{~min}$ during the 1st hour, every 30 min during the 2 nd and 3 rd hours and every 60 min during the 4th and 5th hours. Half of each blood sample was added to a tube containing $5.5 \mathrm{ml}$ of a solution of dihydrosulphosalicylic acid $(64 \cdot 7 \mathrm{~g} / \mathrm{l})$, thiodiglycol $(6 \mathrm{ml} / 1)$ and norleucine $(200 \mathrm{mmol} / 1)$. The tubes were stirred and stored at $-80^{\circ}$. Free AA were extracted by ultrasonic grinding three times for $1 \mathrm{~min}$, each using discontinuous pulses, followed by centrifugation $(6000 \mathrm{~g}$, $20 \mathrm{~min}$ ), collection of the supernatant fraction and adjustment to $\mathrm{pH} 2 \cdot 2$. The determination of AA was made using an automatic analyser (Moore et al. 1958). Immunoreactive insulin and glucagon were measured in the plasma: the remaining $2 \mathrm{ml}$ of each blood sample was collected in ice-chilled tubes containing $10 \mu \mathrm{l}$ heparin and $500 \mathrm{KIU}$ Trasylol (apronitin)/ml blood. Plasma samples were rapidly prepared after centrifugation $\left(1600 \mathrm{~g}, 4^{\circ}, 15 \mathrm{~min}\right)$ and stored at $-80^{\circ}$ until assay. Insulin was measured with a commercial assay system (CEA, France; Sorin Biomedica, Spa, Italy) and glucagon with another commercial system (Novopharmaceutic, Copenhagen, Denmark) (Rérat et al. 1985a).

\section{Calculations and statistical methods}

The net appearance of AA in the portal vein was calculated by the formulas (Rérat et al. 1980):

$$
\begin{gathered}
q=\left(C_{p}-C_{a}\right) D d t, \\
Q=\sum_{t_{9}}^{t_{1}} q,
\end{gathered}
$$

where $q$ is the quantity absorbed during the short time $d t(5 \mathrm{~min})$ during which the factors could be considered as constant, $C_{p}$ is the portal concentration, $C_{a}$ is the arterial concentration, $D$ is the flow in the portal vein and $Q$ is the quantity that appeared during the post-infusion period between times $t_{0}$ and $t_{1}$.

This measurement does not involve the total absorption but only the net influx of nutrients in the portal blood, as some nutrients coming from the intestinal lumen or from the arterial blood may be metabolized in the gastrointestinal wall. For an infused nutrient, the recorded values correspond to the excess of absorption over gut metabolism when the porto-arterial difference is positive or to the excess of gut tissue metabolism relative to the absorption when the porto-arterial difference is negative. On the other hand, the synthesis of a non-infused substance by the gastrointestinal wall or of a hormone by the endocrine gastrointestinal system can be measured in this way (Rérat et al. 1980).

Statistical analysis (Snedecor \& Cochran, 1967) involved standard error of the mean, comparison of two groups of equal or unequal size by Student's $t$ test and regression analysis.

\section{RESULTS}

\section{Portal blood flow-rate}

The type of infusion did not affect the blood flow pattern: for all animals and experiments ( $n$ 24), the portal blood flow-rate $(5 \mathrm{~h}$ mean) was 2310 (SEM 99) $\mathrm{ml} / \mathrm{min}$, i.e. 34.4 (SEM 1.4) $\mathrm{ml} / \mathrm{kg}$ per min. The variations after infusion were similar to those observed after a meal (Rérat et al. 1985a). 

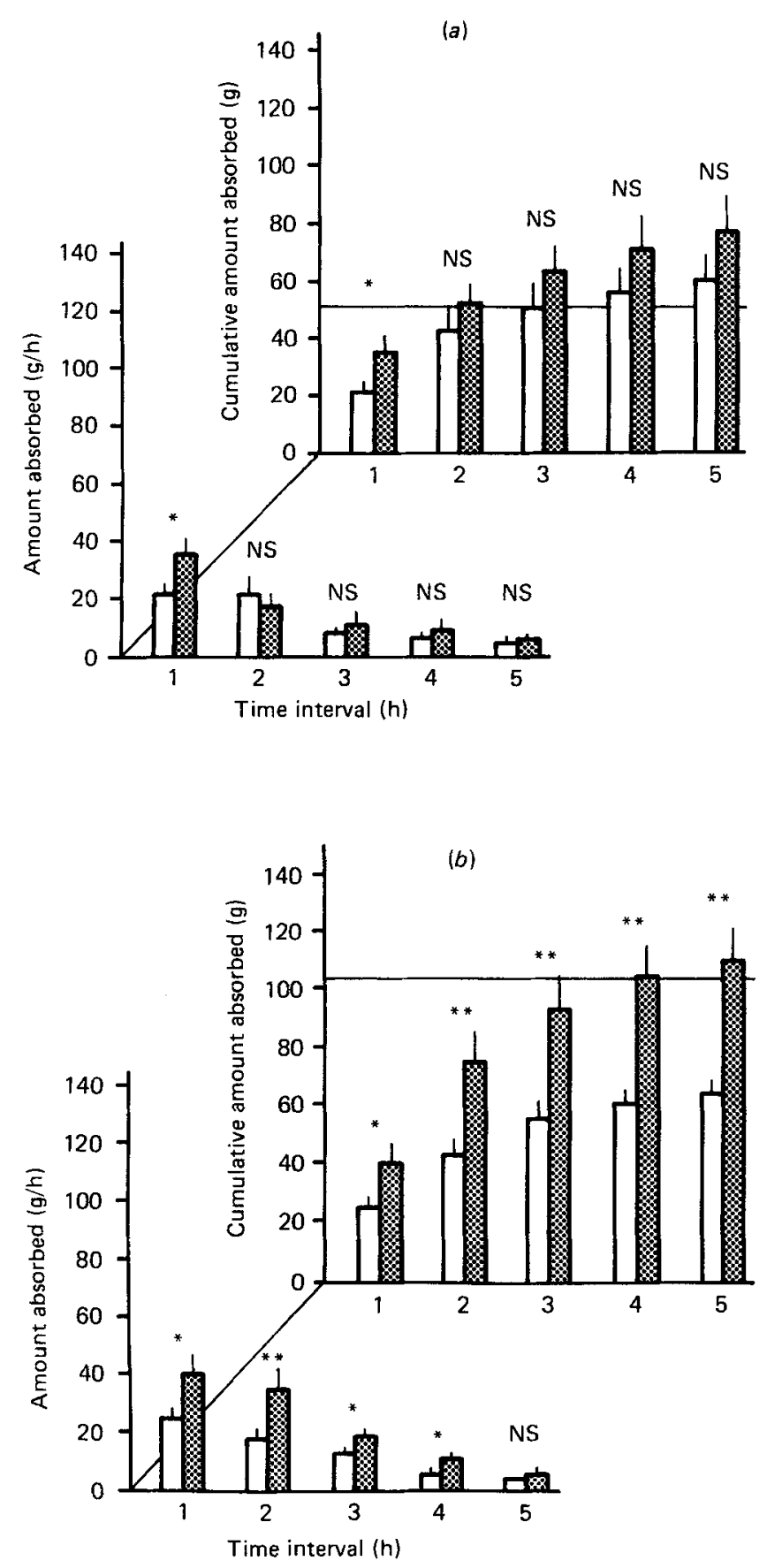

Fig. 1. Appearance of total amino acids in portal blood after duodenal infusion of solutions containing (a) 55 or $(b) 110 \mathrm{~g}$ free amino acids $(\square)$ or milk-protein hydrolysate $(\mathrm{B})$. ( $\longrightarrow$ ) Infused quantity. Statistical significance of difference between infusates $(n 6)$ : NS, not significant ; $P<0.05,{ }^{* *} P<0.01$. Values are means with their standard errors represented by vertical bars. For details of infusions, see p. 122 . 


\section{Post-infusion variations in total $A A$ absorption}

Whatever the type and the quantity of infusion, total AA appeared early in the portal vein, $65-69 \%$ being absorbed during the first $2 \mathrm{~h}$ (Fig. 1). It was particularly during this period that the absorption of AA from PEP occurred earlier and at a greater rate than that from the AAL solution. After infusion of $55 \mathrm{~g}$, these differences were significant between 0 and $60 \mathrm{~min}$; after infusion of $110 \mathrm{~g}$, they were significant between 30 and $240 \mathrm{~min}$. After infusion of $110 \mathrm{~g}$ these differences in absorption between the two types of solutions remained very marked until the 5 th hour, whereas when the smaller amount was infused they decreased and disappeared. Thus, after $5 \mathrm{~h}$ the difference in the total amounts of the two solutions absorbed was not significant after infusion of $55 \mathrm{~g}$, but was significant after infusion of $110 \mathrm{~g}(P<0.01)$.

The influence of the amounts infused on amounts absorbed per hour was very marked when the solution was essentially composed of peptides, the absorption being significantly higher after infusion of $110 \mathrm{~g}$ than after $55 \mathrm{~g}$ at the 2nd and 4th hours, and for the total period. In the case of free AA (AAL), the hourly amounts absorbed after infusion of $110 \mathrm{~g}$ were almost the same as those after $55 \mathrm{~g}$ except during the $3 \mathrm{rd}$ hour when small differences were observed $(P<0.05)$. Accordingly, the hourly AA absorption seemed to reach a plateau after infusion of free AA while this was not the case after infusion of PEP, at least in the present experimental conditions.

The cumulative amounts of total AA absorbed during the post-infusion period of $5 \mathrm{~h}$ generally exceeded the amounts infused, except for $110 \mathrm{~g} \mathrm{AAL}$. The AA absorbed in excess were $4.9 \mathrm{~g}$ with $55 \mathrm{~g}$ AAL, 22.1 $\mathrm{g}$ with $55 \mathrm{~g}$ PEP and $2.0 \mathrm{~g}$ with $110 \mathrm{~g}$ PEP (i.e. 8.9, 40.1 and $1.8 \%$ respectively of the infused amounts). At $5 \mathrm{~h}$ after infusion of $110 \mathrm{~g} \mathrm{AAL}$, only $55.8 \mathrm{~g}$ of the infused AA had appeared in the portal vein (i.e. a deficit of $40 \%$ ).

\section{Post-infusion variations in absorption of individual $A A$}

For each infusion type the absorption pattern of most AA resembled that of their sum. With a few exceptions the amount of each AA which had appeared in the portal vein by $2 \mathrm{~h}$ after the infusion corresponded to more than two-thirds of the total absorption measured over $5 \mathrm{~h}$. This varied somewhat according to the AA considered and the type of infusion. When comparing the two kinds of infusate, AA (with the exception of methionine) appeared in the portal vein more rapidly and in greater quantities after PEP infusion than after AAL. These differences are illustrated by the results obtained with lysine (Fig. 2) and methionine (Fig. 3).

Using the absorption coefficients (amount appearing in the portal vein/amount infused) of each AA calculated for a period of 1 or $5 \mathrm{~h}$ for infusions of $55 \mathrm{~g}$ (Fig. 4) or $110 \mathrm{~g}$ (Fig. 5), it was possible to determine differences in absorption rate of a given AA according to the solution infused and between AA for a given type of infusion.

Whatever the amounts perfused, the absorption rates of histidine, lysine, phenylalanine, threonine, arginine, tyrosine, serine and alanine were significantly higher $1 \mathrm{~h}$ after infusion of PEP than after AAL; it was significantly lower for methionine. Except for tyrosine and methionine these differences remained significant after $5 \mathrm{~h}$ for infusions of $110 \mathrm{~g}$ but, except for threonine and alanine, were not significant for $55 \mathrm{~g}$.

During the 1st hour after infusion of $55 \mathrm{~g} \mathrm{AAL}$, the differences in absorption rate between AA were particularly marked. With the exception of cystine ( 0.08$)$, the absorption coefficients of essential AA ranged from 0.19 to 0.71 (mean 0.47) and those of non-essential AA from 0.07 to 0.64 (mean 0.31 ). At $1 \mathrm{~h}$ after infusion of $110 \mathrm{~g} \mathrm{AAL}$, the absorption coefficients of essential AA varied from 0.10 to 0.44 (mean 0.27 ) and those of non-essential AA from 0.05 to 0.46 (mean 0.19 ). For the two levels of infusion, the early absorption rates 

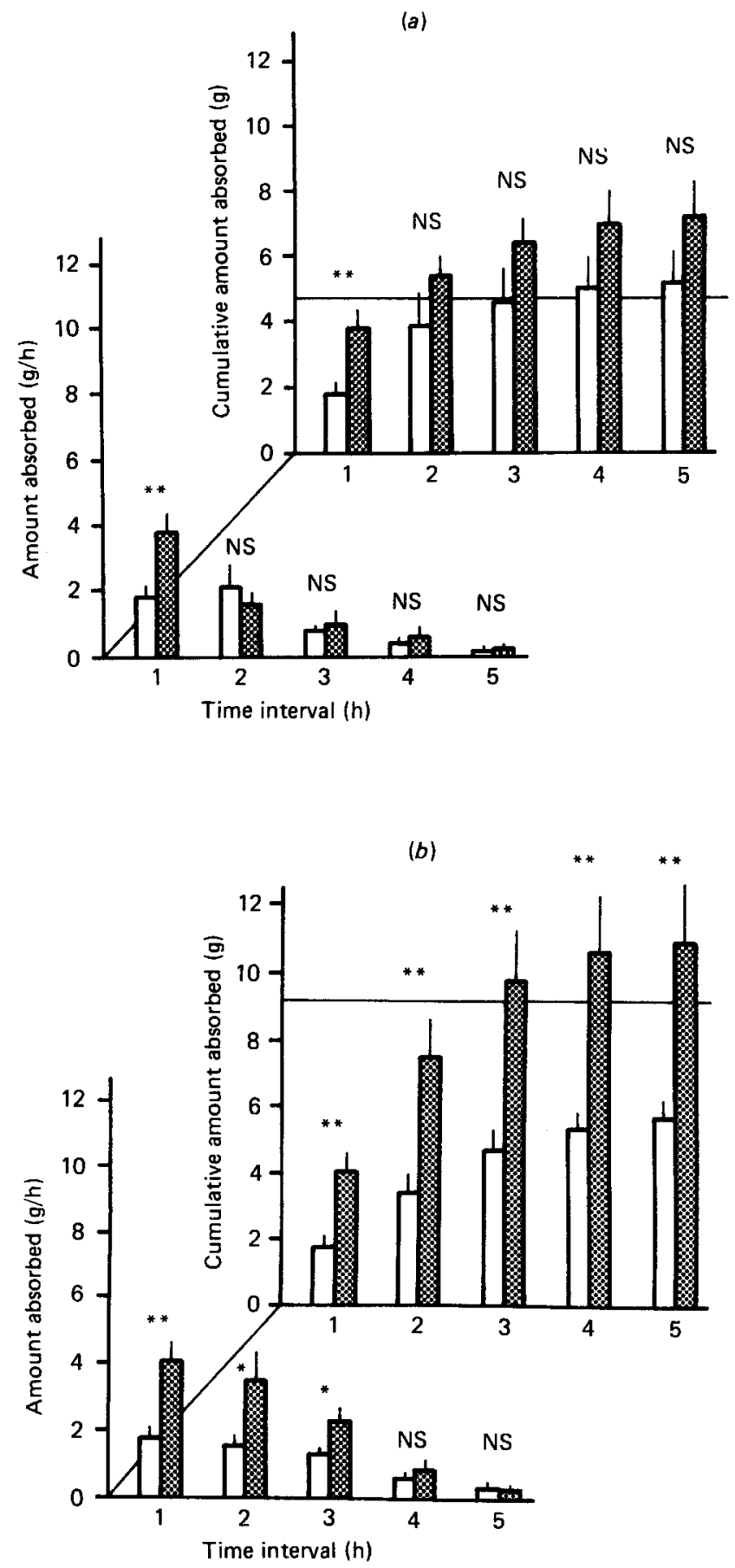

Fig. 2. Appearance of lysine in portal blood after duodenal infusion of solutions containing ( $a$ ) 55 or (b)

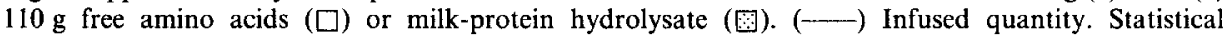
significance of difference between infusates $(n 6)$ : NS, not significant; ${ }^{*} P<0.05,{ }^{*} P<0.01$. Values are means with their standard errors represented by vertical bars. For details of infusions see p. 122. 


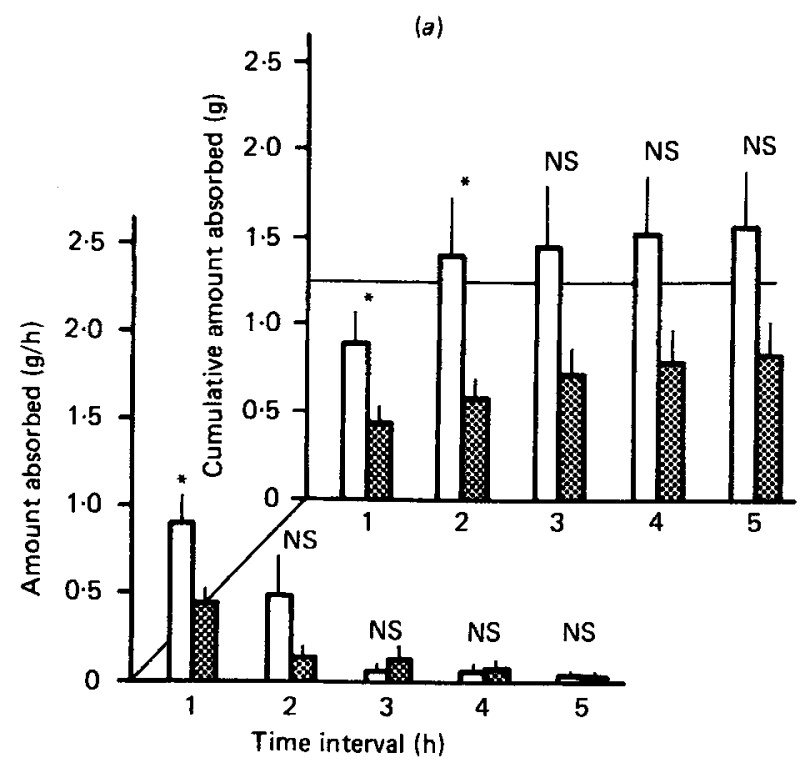

(b)

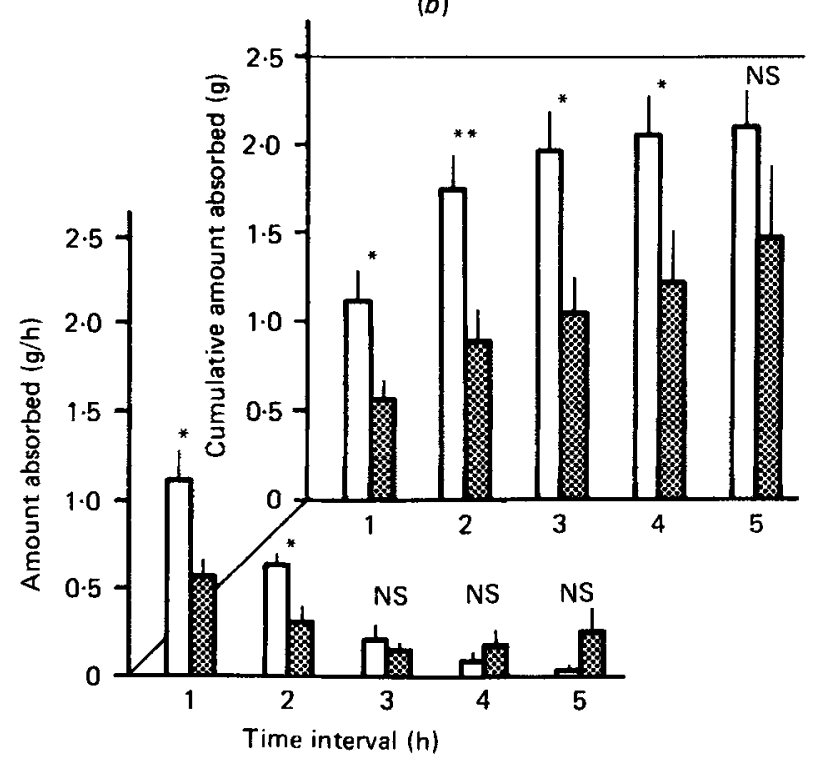

Fig. 3. Appearance of methionine in portal blood after duodenal infusion of solutions containing (a) 55 or $(b) 110 \mathrm{~g}$ free amino acids $(\square)$ or milk-protein hydrolysate $(\square)$. ( $(-)$ Infused quantity. Statistical significance of difference between infusates $(n 6)$ : NS, not significant; ${ }^{*} P<0 \cdot 05,{ }^{* *} P<0 \cdot 01$. Values are means with their standard errors represented by vertical bars. For details of infusions, see p. 122. 


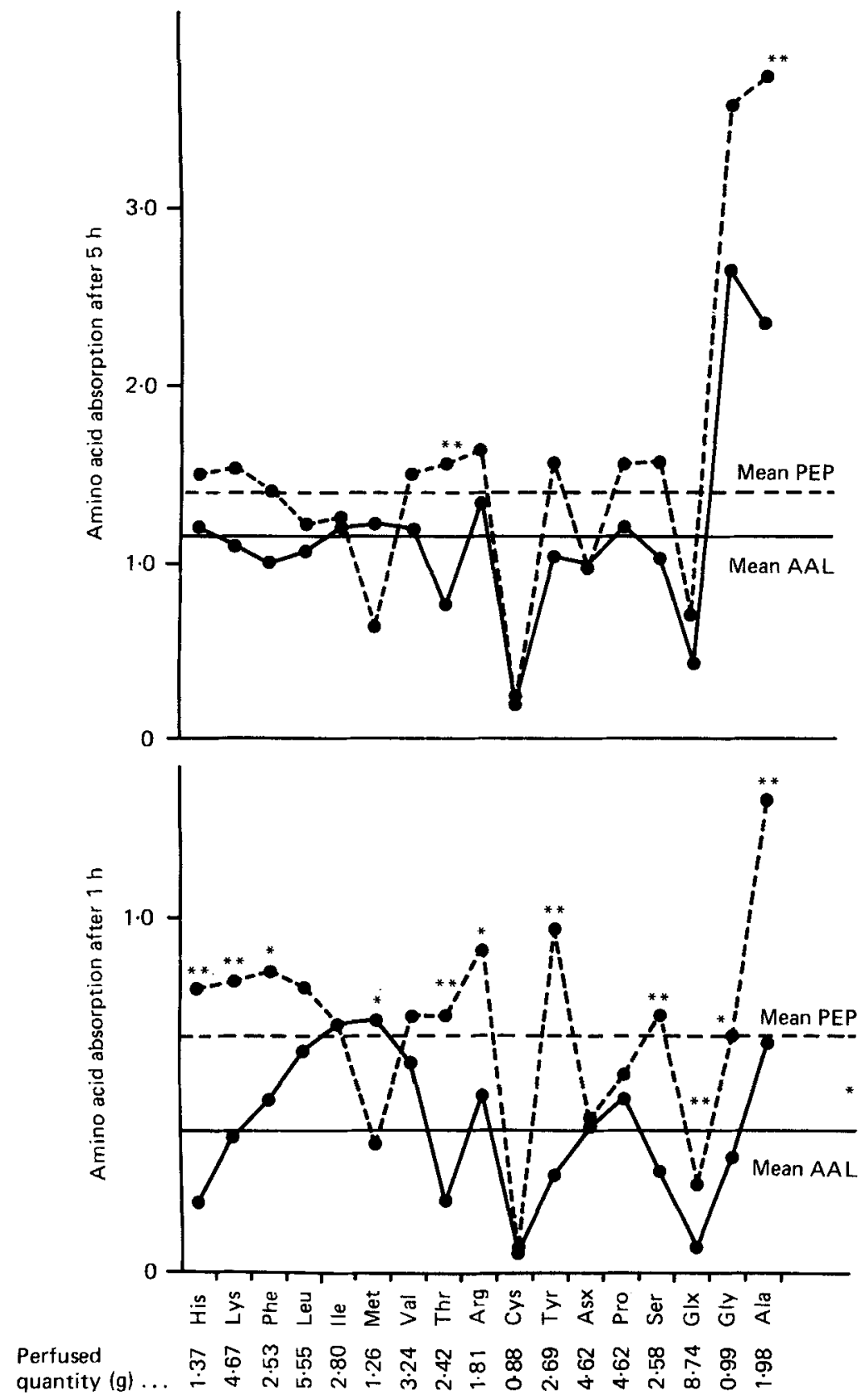

Fig. 4. Absorption coefficients (amount absorbed/amount infused) of amino acids after duodenal infusion of solutions containing $55 \mathrm{~g}$ free amino acids (-) or $55 \mathrm{~g}$ milk-protein hydrolysate (-- $)$. His, histidine; Lys, lysine; Phe, phenylalanine; Leu, leucine; Ile, isoleucine; Met, methionine; Val, valine; Thr, threonine; Arg, arginine ; Cys, cystine; Tyr, tyrosine; Asx, aspartic acid + asparagine; Pro, proline; Ser, serine; Glx, glutamic acid + glutamine; Gly, glycine; Ala, alanine. Statistical significance of difference between infusates $(n 6):{ }^{*} P<0.05,{ }^{* *} P<0.01$. For details of infusions, see p. 122 . 

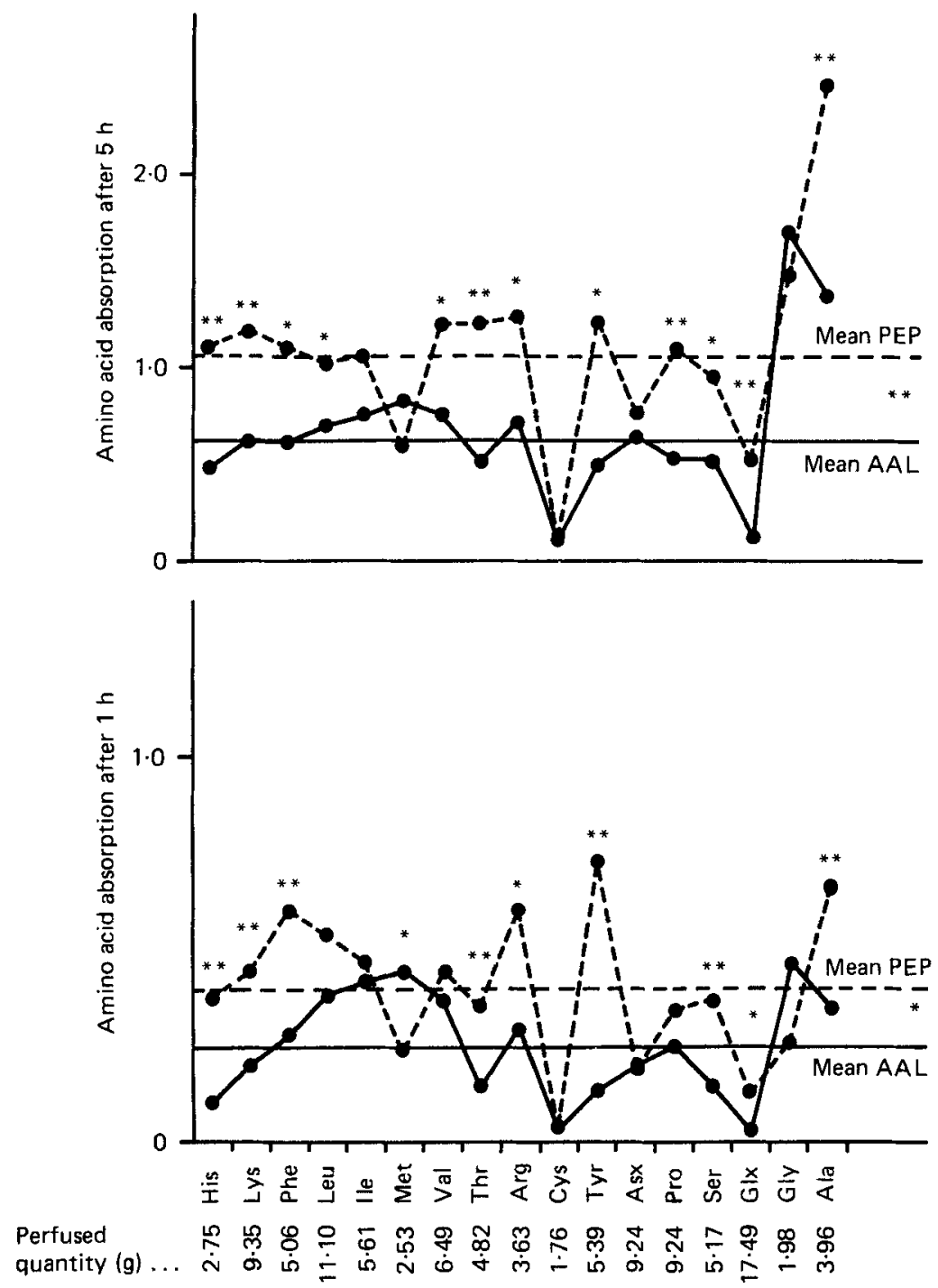

Fig. 5. Absorption coefficients (amount absorbed/amount infused) of amino acids after duodenal infusion of solutions containing $110 \mathrm{~g}$ free amino acids $(-)$ or $110 \mathrm{~g}$ milk-protein hydrolysate $(--)$. His, histidine; Lys, lysine; Phe, phenylalanine; Leu, leucine; Ile, isoleucine; Met, methionine; Val, valine; Thr, threonine; Arg, arginine; Cys, cystine; Tyr, tyrosine; Asx, aspartic acid + asparagine; Pro, proline; Ser, serine; Glx, glutamic acid + glutamine; Gly, glycine; Ala, alanine. Statistical significance of difference between infusates $(n 6):{ }^{*} P<0.05,{ }^{* *} P<0.01$. For details of infusions, see p. 122.

were higher than the mean for leucine, isoleucine, valine, methionine and alanine, and lower than the mean for histidine, threonine, serine, glutamic acid + glutamine, tyrosine and especially cystine. For the same period of time, the early absorption of individual AA was on average much higher after infusion of $55 \mathrm{~g}$ PEP (0.67) than AAL (0.40) and much more homogeneous, $0.69-0.96$ for essential AA (mean 0.76) and $0.26-1.33$ for non-essential AA (mean 0.58). The exceptions were the sulphur-AA which were absorbed slowly in the 1st hour (methionine 0.35 , cystine 0.05 ). The absorption rates for all AA were higher after infusion of $110 \mathrm{~g}$ PEP than after infusion of the same amount of AL $(0.39 v 0.24)$; they 
Table 2. Synthesis and uptake of amino acids $(\mathrm{g})$ by the gastrointestinal tract during $5 \mathrm{~h}$ after duodenal infusion of a solution containing 55 or $110 \mathrm{~g}$ free amino acids $(A A L)$ or milk-protein hydrolysate $(P E P)^{*}$

(Mean values with their standard errors)

\begin{tabular}{|c|c|c|c|c|c|c|c|c|}
\hline \multirow{3}{*}{$\begin{array}{l}\text { Infused amount }(\mathrm{g}) \ldots \\
\text { Infusate type... }\end{array}$} & \multicolumn{4}{|c|}{55} & \multicolumn{4}{|c|}{110} \\
\hline & \multicolumn{2}{|c|}{ AAL } & \multicolumn{2}{|c|}{ PEP } & \multicolumn{2}{|c|}{ AAL } & \multicolumn{2}{|c|}{ PEP } \\
\hline & Mean & SEM & Mean & SEM & Mean & SEM & Mean & SEM \\
\hline \multicolumn{9}{|l|}{ Uptake $(\mathrm{g} / 5 \mathrm{~h})$} \\
\hline Glutamine & $4 \cdot 52$ & 1.20 & $2 \cdot 28$ & 0.46 & $4 \cdot 27$ & $0 \cdot 80$ & 1.87 & 0.84 \\
\hline Cystine & $0 \cdot 31$ & 0.12 & $0 \cdot 11$ & 0.07 & $0 \cdot 26$ & $0 \cdot 10$ & $0 \cdot 23$ & 0.03 \\
\hline \multicolumn{9}{|l|}{ Synthesis $(\mathrm{g} / 5 \mathrm{~h})$} \\
\hline Asparagine & $3 \cdot 24$ & 0.68 & $2 \cdot 56$ & 0.58 & $4 \cdot 11$ & $0 \cdot 31$ & 3.84 & 0.57 \\
\hline Ornithine & 0.72 & 0.13 & 0.96 & 0.27 & 0.74 & $0 \cdot 24$ & 0.83 & 0.15 \\
\hline Citrulline & $1 \cdot 56$ & $0 \cdot 26$ & $2 \cdot 37$ & $0 \cdot 32$ & $1 \cdot 16$ & 0.19 & $1 \cdot 90$ & $0 \cdot 26$ \\
\hline Taurine & 1.89 & $0 \cdot 38$ & 1.25 & $0 \cdot 34$ & $1 \cdot 31$ & 0.50 & 1.34 & 0.29 \\
\hline
\end{tabular}

* For details, see p. 122.

Table 3. Absorption balance of organic sulphur 5 h after duodenal infusion of a solution containing 55 or $110 \mathrm{~g}$ free amino acids $(A A L)$ or milk-protein hydrolysate $(P E P)^{*}$

\begin{tabular}{|c|c|c|c|c|c|c|c|}
\hline \multirow{3}{*}{$\begin{array}{l}\text { Infused } \\
\text { amount } \\
\text { (AAL or } \\
\text { PEP) (g) }\end{array}$} & \multirow[b]{3}{*}{$\begin{array}{l}\text { Amino } \\
\text { acid }\end{array}$} & & & \multicolumn{4}{|c|}{ Absorbed substrate (g) } \\
\hline & & \multicolumn{2}{|c|}{ Infused substrate (g) } & \multicolumn{2}{|c|}{ After AAL } & \multicolumn{2}{|c|}{ After PEP } \\
\hline & & $\begin{array}{l}\text { Infused } \\
\text { amount }\end{array}$ & $\begin{array}{l}\text { Infused } \\
\text { organic } S\end{array}$ & $\begin{array}{l}\text { Amino } \\
\text { acids }\end{array}$ & Organic $S$ & $\begin{array}{l}\text { Amino } \\
\text { acids }\end{array}$ & Organic S \\
\hline \multirow[t]{4}{*}{55} & Methionine† & $1 \cdot 27$ & 0.27 & $1 \cdot 56$ & $0 \cdot 33$ & $0 \cdot 82$ & $0 \cdot 18$ \\
\hline & Cystinet & 0.88 & $0 \cdot 23$ & $0 \cdot 18$ & 0.05 & $0 \cdot 18$ & 0.05 \\
\hline & Taurine $\dagger$ & - & - & $1 \cdot 89$ & 0.43 & $1 \cdot 25$ & $0 \cdot 32$ \\
\hline & Total & - & 0.51 & - & 0.87 & -- & 0.54 \\
\hline \multirow[t]{4}{*}{110} & Methionine $\dagger$ & $2 \cdot 53$ & $0 \cdot 54$ & $2 \cdot 10$ & 0.45 & 1.48 & $0 \cdot 32$ \\
\hline & Cystinet & 1.76 & 0.47 & $0 \cdot 12$ & 0.03 & $0 \cdot 16$ & 0.04 \\
\hline & Taurinet & - & - & 1.31 & $0 \cdot 34$ & $1 \cdot 34$ & 0.34 \\
\hline & Total & - & 1.01 & - & 0.82 & - & 0.71 \\
\hline
\end{tabular}

* For details, see p. 122.

$\dagger \mathrm{S}$ (mg/g amino acid): methionine 215 , cystine 297 , taurine 256.

varied from 0.34 to 0.73 for essential AA (mean 0.48 ) and from 0.12 to 0.65 for non-essential AA (mean 0.27). S-AA were ranked in a special position (methionine 0.23 , cystine 0.03 ). For the two levels of infusion, the early absorption rates of several AA, in addition to methionine and cystine, were lower than the mean (aspartic acid + asparagine and glutamic acid + glutamine) and those of others higher (phenylalanine, leucine, arginine, tyrosine and alanine).

At $5 \mathrm{~h}$ after infusion, the absorption pattern was the same but the differences between AA disappeared more completely after $55 \mathrm{~g}$ than after $110 \mathrm{~g}$ infusions. At $5 \mathrm{~h}$ after infusion of AAL, whatever the amount, only small differences relative to the mean were observed; these were deficits of glutamic acid + glutamine, threonine and cystine and excesses of 
Duodenal infusions of nitrogen products

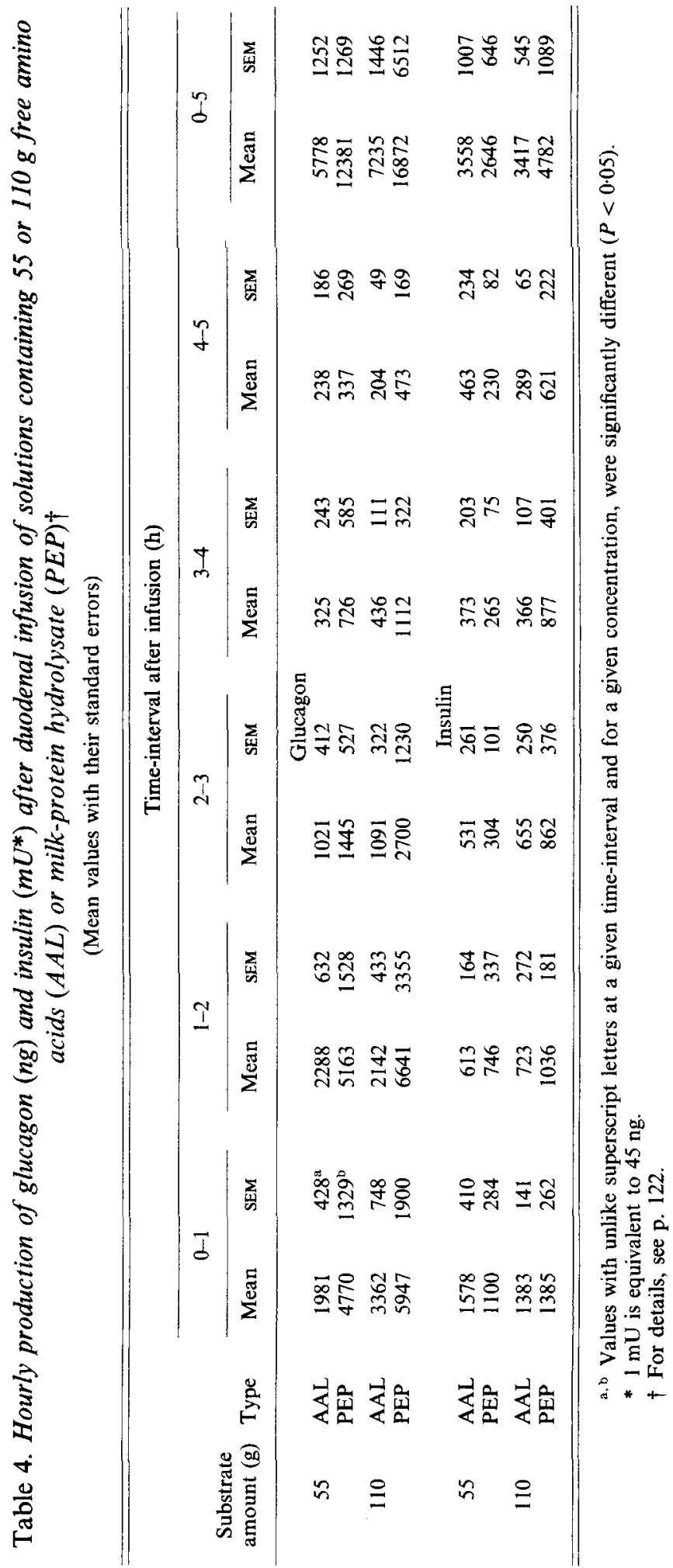


alanine and glycine. At $5 \mathrm{~h}$ after infusion of PEP, the total absorption coefficient was very high, but for methionine and glutamic acid + glutamine remained low, for cystine very low and for glycine and alanine very high. Thus, $5 \mathrm{~h}$ after infusion of either 55 or $110 \mathrm{~g}$, the absorption coefficients after PEP greatly exceeded those recorded after AAL but in both cases there were marked deficiencies of glutamic acid + glutamine and cystine and large excesses of glycine and alanine in the absorbed mixtures. Another particular characteristic was a marked threonine deficiency after infusion of AAL, and of methionine after PEP.

The porto-arterial differences in cystine (often) and glutamine (always) were negative. These AA were taken up by the intestinal tissue (Table 2). The uptake of glutamine was much more marked after infusion of AAL than after PEP, the difference being twofold after $5 \mathrm{~h}$. The uptake of cystine was much lower, but after $5 \mathrm{~h}$ was more marked with AAL than with PEP infusion.

The very large appearance of asparagine, citrulline, ornithine and taurine in the portal blood should also be emphasized (Table 2); of these only asparagine synthesis increased with the amount infused. As regards organic $\mathrm{S}$, the $5 \mathrm{~h}$ absorption balance showed a large excess of absorption after infusion of $55 \mathrm{~g} \mathrm{AAL}$ and a small excess after PEP infusion (Table 3).

\section{Insulin and glucagon production}

The largest amounts of insulin were produced during the 1st hour (about $50-70 \mu \mathrm{g} / \mathrm{h}$ ), i.e. $30-45 \%$ of the total $5 \mathrm{~h}$ production (Table 4). There was no significant difference according to the type of solution infused.

The amount of glucagon produced during the 1st hour after infusion $(2-6 \mu \mathrm{g} / \mathrm{h})$ represented $3449 \%$ of the total amount secreted in the $5 \mathrm{~h}$ after infusion (Table 4). Although the secretion after PEP was more than twofold greater than after AAL for each amount infused, the only significant difference between the infusion solutions was recorded during the 1 st hour after infusion of $55 \mathrm{~g}$. If all values for glucagon production were pooled, irrespective of the level of infusion (which was possible as they were not significantly different from one level to another for a given solution), the difference was also significant during the 2 nd hour.

The hourly production of insulin appeared to be correlated with the absorption of the sum of AA $(r 0.81, n 20)$. It showed high correlations with the absorption of leucine ( $r 0.87)$, arginine $(r 0.84)$ and phenylalanine $(r 0.83)$, but low correlations with the absorption of histidine and threonine $(r 0.69)$. Correlations between glucagon production and hourly absorption of the sum of AA $(r 0.93, n 20)$ as well as that of most of the essential AA appeared to be very high ( $r$ values between 0.89 and 0.94$)$, except for arginine $(r 0.83)$ and methionine $(r 0.76)$.

\section{DISCUSSION}

The present study showed that AA appeared more rapidly in the portal vein after duodenal infusion of the products of mild enzymic hydrolysis of milk than after infusion of a mixture of free AA of the same composition. The composition of the absorbed AA mixture was modified and the absorption of methionine, in particular, was slower after infusion of the hydrolysate than after free AA. These findings confirm results obtained in man (Crampton et al. 1971; Silk et al. 1973). However, the differences in absorption between AA shown by some authors (Silk et al. 1974, 1975) were much smaller, most probably because of the very large percentage of free AA $(30-50 \%)$ in their hydrolysates. It should be pointed out that the hydrolysates used in the present experiment contained few contaminants $(8 \%$ of free AA), and a very large percentage $(80 \%)$ of peptides with a molecular weight under 1500 (60\% containing less than five AA residues). It has been claimed (Silk et al. 1985) that the 
absorption rate of hydrolysates is higher when the chain length of most of their peptides does not exceed five AA residues than when it ranges between ten and fifteen residues. Furthermore, the absorption rate of an ovalbumin hydrolysate containing mainly di- and tripeptides is higher than that of one containing tetra- and pentapeptides (Rees et al. 1984). The chain length of some peptides present in our hydrolysate was perhaps excessively long. It should also be pointed out that duodenal infusions were carried out in animals with a normal pancreatic secretion, which could therefore partially or fully hydrolyse the infused peptides. To resolve this question further, the same comparison should be made in animals deprived of their pancreatic secretion. In addition, as the absorption rates of AA from some dipeptides seem to be higher in the jejunum than in the ileum in the rat (Crampton et al. 1973) and man (Silk et al. 1974), it would be interesting to determine more accurately whether this is true too in the pig by comparing the absorption efficiency of our more complex hydrolysate at the duodenal, jejunal and ileal levels. Thus, more knowledge is required concerning the optimal chain length of peptides, the role of enzymes, and the site of infusion for obtaining the full utilization of these hydrolysates when they are used without any supplementary supply of energy.

Concerning this last question, it has been established that the supply of carbohydrates affects the absorption rate of hydrolysates more than that of free AA (Simoes Nunes et al. 1987). The differences between the two types of solutions were only to the advantage of the hydrolysates during the first $2 \mathrm{~h}$ after infusion, thereafter turning to their disadvantage for the next $2 \mathrm{~h}$ so that amounts absorbed after $4 \mathrm{~h}$ were the same in both cases (Simoes Nunes et al. 1987). This early absorption may, however, be an advantage in terms of the stimulation of endocrine secretions of insulin and glucagon (Unger et al. 1976).

Total amounts of absorbed AA in the portal vein generally exceeded the amounts infused, except with infusions of $110 \mathrm{~g} \mathrm{AAL}$. The excess was particularly high in the case of $55 \mathrm{~g}$ PEP, representing $35-40 \%$ of the amount infused; it would certainly also be much higher than that observed after infusion of $110 \mathrm{~g}$ PEP, the absorption of which was not finished by the end of the trial. The recycling of endogenous $N$ (e.g. digestive secretions and desquamated cells) which in normal feeding conditions correspond to the absorption of $2 \mathrm{~g} \mathrm{AA} / \mathrm{h}$ (Rérat et al. 1977; Rérat, 1982) may account for this excess of absorption relative to amounts infused. However, the amounts recycled in the present study after infusion of hydrolysate were much higher $(4.5 \mathrm{~g} / \mathrm{h}$ after $55 \mathrm{~g}$ PEP). It would therefore be necessary to determine more accurately the origin of this increase in the absorption of endogenous $\mathrm{N}$. It may be due to a stimulation of secretion by some of the small peptides present in the hydrolysate, combined with an early self-hydrolysis of digestive fluids because of the absence of protein substrates. It may also be due to the absence of carbohydrates in the infusion solutions, thus reducing the synthesis in the gut wall and increasing the appearance of AA in the portal blood. This, however, does not explain differences in recycling between AAL and PEP.

The present studies concerning the appearance of AA in the portal blood demonstrate and quantify some metabolic processes in the intestinal cell wall. In addition to the direct uptake of AA for tissue synthesis, gut-wall metabolism leads to the appearance in the blood of groups of substances at the expense of infused or circulating AA. Thus, the $5 \mathrm{~h}$ balance of glutamic acid + glutamine was always very low, which cannot be explained only by a very low absorption rate (Rérat et al. 1976). Likewise, a large proportion of blood glutamine disappeared during blood passage through the intestinal tissue as shown elsewhere (Rérat et al. 1976). Conversely, very large amounts of alanine and smaller amounts of citrulline and ornithine were found. Ornithine seemed to be derived from dietary or infused arginine (one-third of which is metabolized in the gut tissue in the rat) and aspartic acid (Windmueller \& Spaeth, 1976). Most synthesized ornithine seems thereafter to be 
metabolized into citrulline, proline, glutamine, organic acids and carbon dioxide. Citrulline also appears to be derived from blood glutamine, producing simultaneously ammonia, alanine and proline (Windmueller \& Spaeth, 1976, 1980). Alanine would thus not only be synthesized from dietary glutamic acid (Rérat et al. 1976; Windmueller \& Spaeth, 1976; Rérat, 1982), but also from blood glutamine, ornithine and citrulline, accounting for the large excesses of this AA in portal blood. The very low absorption of glutamic acid and poor absorption of arginine and aspartic acid might be explained by their involvement in the synthesis of alanine, ornithine and citrulline.

The appearance of large amounts of taurine in the portal vein may have two origins. The metabolism of S-AA of exogenous or endogenous origin in the intestinal cell wall may lead to a synthesis of taurine. As glutathione, which is present in large amounts in blood and which can be synthesized in large quantities by the gut wall (Elwyn et al. 1968), was not measured, it was difficult to establish a full balance of $S$ substances in the intestinal cell wall. Considering the infused S-AA, the methionine balance $5 \mathrm{~h}$ after infusion of AAL was in excess (for the $55 \mathrm{~g}$ level) or showed a slight deficit (for $110 \mathrm{~g}$ ); the deficit was very marked after infusion of a mixture essentially composed of peptides. The cystine balance was almost zero in all cases. It has been established that cystine may be metabolized into taurine (Hayes, 1985) and this may account for the low net absorption. However, on the basis of its $\mathrm{S}$ content, taurine showed a large excess relative to infused cystine in the case of infusion of $55 \mathrm{~g} \mathrm{AAL}(181 \%)$ and $55 \mathrm{~g}$ PEP $(137 \%)$. Some part of this excess could also be explained by the recycling of taurine present in the gut lumen as conjugated bile salts; the amount of taurine secreted in bile by the pig for $5 \mathrm{~h}$ after a normal meal is on average $125 \mathrm{mg}$ (V. Legrand-Defretin, unpublished results). However, taurine synthesis did not compensate for the low appearance of methionine in the portal blood after PEP infusion, even if the methionine and cystine in the pancreatic secretions are taken into account. The total quantity of these AA secreted into the pig gut lumen by the pancreas in $5 \mathrm{~h}$ is approximately $130 \mathrm{mg}$ (Corring, 1975).

The hourly glucagon secretion was highly correlated with the hourly total AA absorption. This relation confirms that already observed during the post-prandial period in the pig (Rérat et al. 1985a). It may therefore be concluded that this secretion was proportional to the amounts of AA absorbed, which were larger after infusion of small peptides and greater amounts infused. This could be an argument for a stimulation of glucagon secretion by AA (Eisenstein et al. 1979). Glucagon production was, however, smaller than that recorded after consumption of mixed diets with variable carbohydrate contents (Rérat et al. 1985a).

Insulin production recorded during the first hour after infusion was three- to fivefold lower than after ingestion of meals containing 0,140 or $280 \mathrm{~g}$ protein $/ \mathrm{kg}$ (Rérat et al. 1985a). Several mechanisms may explain this insulin response in the absence of glucose. First, some AA such as arginine (Atinmo et al. 1978), lysine and leucine (Fajans et al. 1967) stimulate insulin secretion and the absorption of these AA is high after the infusion. Second, we also know that glucagon, the production of which is stimulated by the infusion, stimulates the secretion of insulin (Samols et al. 1972). Third, the secretion of gastric inhibitory polypeptide (GIP) is stimulated by duodenal infusions of AA, but its insulinotropic effect is only potentiated in hyperglycaemia (Yovos et al. 1982). The absence of absorbed carbohydrates might explain why insulin secretion was the same whatever the level and type of infusion.

It may be concluded that absorption of AA was more efficient after infusion of PEP than of AAL, both in terms of rate and time-course; this was the case for total AA and for most essential and non-essential AA. However, the efficiency was not higher in the case of PEP for isoleucine, aspartic acid + asparagine or glutamic acid + glutamine and was much lower 
for methionine. Compared with infusion of free AA a more homogeneous absorption was observed after infusion of the mixture composed mainly of small peptides; the deficits persisting after $5 \mathrm{~h}$ mainly concerned methionine, cystine, aspartic acid + asparagine and glutamic acid + glutamine.

Thus, after duodenal infusion of a mixture containing mainly small peptides there was a larger absorption of AA, probably because there was no competition for the transport sites as in the case of free AA. This massive influx of AA in the portal vein stimulated the secretion of glucagon and this stimulation was much more marked for a period of $2 \mathrm{~h}$ after infusion of a mild hydrolysate of milk-protein than after that of free AA.

The authors thank P. Vaugelade, P. Vaissade, C. Picou, G. Brachet, F. Cointepas and J. Weber for skilful technical assistance, and Kirsten Rérat for translating the manuscript into English. This work was supported by a grant from the Sopharga Laboratory.

\section{REFERENCES}

Atinmo, T. C., Baldijao, C., Houpt, K. A., Pond, W. G. \& Barnes, R. H. (1978). Journal of Animal Science 46, 409-416.

Biological Council (1984). Guidelines on the Use of Living Animals in Scientific Investigations. London: Biological Council.

Chung, Y. C., Silk, D. B. A. \& Kim, Y. S. (1979). Clinical Science 57, 1-11.

Corring, T. (1975). Annales de Biologie Animale, Biochimie, Biophysique 15, 115-118.

Crampton, R. F., Gangolli, S. D., Simson, P. \& Matthews, D. M. (1971). Clinical Science 41, 409 417.

Crampton, R. F., Lis, M. I. \& Matthews, D. M. (1973). Clinical Science 44, 583-594.

Eisenstein, A. B., Strack, I., Gallo-Torres, H., Georgiadis, A. I. \& Miller, O. N. (1979). American Journal of Physiology 5, E20-E27.

Elwyn, D. H., Parikh, H. C. \& Shoemaker, W. C. (1968). American Journal of Physiology 215, 1260-1275.

Fajans, S. S., Floyd, J. C. Jr, Knopf, R. \& Conn, J. W. (1967). Recent Progress on Hormone Research 23 $617-662$.

Hayes, K. C. (1985). Nutrition Reviews 43, 65-70.

Kim, Y. S., Kim, Y. W. \& Sleisenger, M. H. (1974). Biochimica Biophysica Acta 370, 283-296.

Matthews, D. M. \& Adibi, S. A. (1976). Gastroenterology 71, 151-161.

Moore, S., Spackman, D. H. \& Stein, W. H. (1958). Analytical Chemistry 30, 1185-1190.

Rees, R. G., Grimble, G. K., Keohane, P. P., West, M., Spiller, R. C. \& Silk, D. B. A. (1984). Gut 25, A 547.

Rérat, A. (1982). In Digestive Physiology in the Pig: Colloques de l'INRA no. 12 pp. 63-85 [J. P. Laplace, T. Corring and A. Rérat, editors]. Paris: Institut National de la Recherche Agronomique.

Rérat, A., Chayvialle, J. A., Kandé, J., Vaissade, P., Vaugelade, P. \& Bourrier, T. (1985a). Canadian Journal of Physiology and Pharmacology 63, 1547-1559.

Rérat, A., Corring, T. \& Laplace, J. P. (1976). In Protein Metabolism and Nutrition, European Association of Animal Production Publication no. 16, pp. 97-138 [D. J. A. Cole, K. N. Boorman, P. J. Buttery, D. Lewis, R. J. Neale and H. Swan, editors]. London: Butterworths.

Rérat, A., Lacroix, M., Simoes Nunes, C., Vaugelade, P. \& Vaissade, P. (1984). Bulletin de l'Académie Nationale de Médecine 168, 385-391.

Rérat, A., Simoes Nunes, C., Lacroix, M., Vaugelade, P. \& Vaissade P. (1985 b). Comptes Rendus de l'Académie des Sciences 300, 293-296.

Rérat, A., Vaissade, P., Vaugelade, P., Robin, D., Robin, P. \& Jung, J. (1977). Fifth International Symposium on Amino Acids, Sect. D3, pp. 1-8, Budapest.

Rérat, A., Vaugelade, P. \& Villiers, P. (1980). In Current Concepts of Digestion and Absorption in Pigs, Technical Bulletin no. 3, pp. 177-216 [A. G. Low and I. G. Partridge, editors]. Reading/Ayr: National Institute for Research in Dairing/Hannah Research Institute.

Samols, R. T., Tyler, J. M. \& Marks, V. (1972). In Glucagon, Molecular Physiology, Clinical and Therapentic Implications, pp. 151-173 [J. P. Lefevre and R. H. Unger, editors]. Oxford: Pergamon Press.

Silk, D. B. A., Clark, M. L., Marrs, T. C., Addison, J. M., Burston, D. \& Matthews D. M. (1975). British Journal of Nutrition 33, 95-110.

Silk, D. B. A., Grimble, G. K. \& Rees, R. G. (1985). Proceedings of the Nutrition Society 44, 63-72.

Silk, D. B. A., Hegarty, J. E., Fairclough, P. D. \& Clark, M. L. (1982). Annals of Nutrition and Metabolism 26, 337-352.

Silk, D. B. A., Marrs, T. C., Clegg, K. M., Addison, J. M., Burston, D., Clark, M. L. \& Matthews, D. M. (1973). Clinical Science and Molecular Medicine 45, 715-716.

Silk, D. B. A., Webb, J. P. W., Lane, A. E., Clark, M. L. \& Dawson, A. M. (1974). Gut 15, $444-449$. 
Simoes Nunes, C., Rérat, A., Vaugelade, P. \& Vaissade, P. (1987). Proceedings of the Nutrition Society 46, 102A.

Sleisenger, M. H., Burston, D., Dalrymple, J. A., Wilkinson, S. \& Matthews, D. M. (1976). Gastroenterology 71 , $76-81$.

Snedecor, G. W. \& Cochran, W. G. (1967). Statistical Methods. Ames, Iowa: Iowa State University Press.

Unger, R. H., Dobbs, R. E. \& Orci, L. (1976). Annual Review of Physiology 40, 307-343.

Windmueller, H. G. \& Spaeth, A. E. (1976). Archives of Biochemistry and Biophysics 175, 670-676.

Windmueller, H. G. \& Spaeth, A. E. (1980). Journal of Biological Chemistry 255, 107-112.

Yovos, J. G., O'Dorisio, T. M., Pappas, T. N., Cataland, S., Thomas, F. B., Mekhjian, S. H. \& Carey, L. C. (1982). American Journal of Physiology 242, E53-E58. 